\title{
WELLNESS TURISZTIKAI UTAZÁSOK SORÁN KIALAKULT EGÉSZSÉGGEL KAPCSOLATOS VISELKEDÉSI SZÁNDÉK RÖVID TÁVÚ HATÁSA AZ EGÉSZSÉGMAGATARTÁSRA
}

\section{SHORT TERM EFFECT OF HEALTH RELATED BEHAVIOUR INTENTION'S FORMED DURING WELLNESS TRAVELLING ON HEALTH BEHAV- IOUR}

\author{
Savella Orsolya
}

Turizmus Vendéglátás Tanszék, Neumann János Egyetem, Gazdálkodási Kar, Magyarország

\author{
Kulcsszavak: \\ Wellness \\ Viselkedési szándék \\ Nem paraméteres próba \\ Rövid távú hatás \\ Egészségmagatartás \\ Keywords: \\ Wellness \\ Behavioural intention \\ Non parametric test \\ Short term effect \\ Health behaviour
}

\begin{abstract}
Összefoglalás
Turisztikai célú utazások magatartásra gyakorolt hatása rövid és hosszú távú lehet, empirikus eredményekkel azonban föként az ökoturizmus területéröl rendelkezünk. Jelen kutatási eredmények az egészségturisztikai utazások során kialakult viselkedési szándék, utazást követő egészségmagatartásra gyakorolt rövid távú hatására koncentrál. A vizsgálat alapvetóen a nemzetközi szakirodalom iránymutatásai alapján készült, eltérést az alkalmazott statisztikai számításokban mutat. Az elemzés a nem paraméteres próbákon belül Kruskal - Wallis teszt, további megerősités céljából a leíró statisztikai számítások közül medián és módusz tesztek felhasználásával történt. A megkérdezettek válaszai alapján az egészségturisztikai utazás egy, az egészség fenntartását és fejlesztését segítő területen jelent meg.
\end{abstract}

\begin{abstract}
The short and long-term effect of tourism on behavior can be verified by empirical studies mainly in ecotourism. The results of present research focus on the short-term impact of behavioral attitudes on health tourism and post-journey health behavior. The study is basically based on the guidelines of international literature, showing a discrepancy in the applied statistical calculations. The analysis was performed in the non-parametric Kruskal-Wallis test, for further confirmation from the descriptive statistical calculations using median and mode tests. According to the responses, the health tourism trips appeared in a field of support for the maintenance and development of health.
\end{abstract}




\section{Bevezetés}

A magyar lakosság egészségmutatói - főként a keringési és rosszindulatú daganatos megbetegedések, valamint az elvesztett egészséges életévek számában - kedvezőtlenebbek az EU fejlettebb tagállamaihoz képest [39]. Bár az 1990-es évek közepétől a társadalom életkilátásai javulnak, átlagosan elmaradnak az EU15 és a visegrádi országoktól [24]. A szabadidős tevékenységhez kapcsolódó tanulás fontossága napjainkban egyre nyilvánvalóbb, melyhez a nem formális és informális tanulás színtereinek gazdagítása és a tanulási lehetőségek bővítése elengedhetetlen. A turizmus, mint aktív szabadidős tevékenység, mind a társadalom egészségi állapotának javításában, mind az életminőség javítása révén kiemelt jelentőséggel bír. A téma szempontjából olyan interventív eszközök és színterek vizsgálatának szükségességére is rámutat, melyek az egészségmegőrzés, illetve jó közérzet előmozdításához járulnak hozzá.

Ilyen egészségmagatartást befolyásoló tanulási környezet lehet a wellness turizmus, ami sajátos eszközeivel - az egészség megtartásához és fejlesztéséhez felhasználható - ismeret-, és tapasztalatszerzésre biztosít lehetőséget. A wellness turizmus fontosságát bizonyítja, hogy az egészségnevelés területén alkalmazott főként verbális tevékenységek kiegészítésére alkalmasak lehetnek azok az aktív, személyesen is kipróbálható egészség-szolgáltatások, melyek alapot adhatnak egy egészségesebb életmód felé vezető változáshoz. A turizmus metodológiai gazdagsága miatt válhat pedagógiaivá, mind a pedagógiai ismeretgazdagításra, mind a gyakorlati problémamegoldásra vonatkozóan [40].

A wellness egyfajta életfilozófia, életforma, mely áthatva a mindennapokat törekszik a betegségek megelőzésére valamint a testi-lelki harmónia kialakítására. Holisztikus szemléletmódja az egészségturizmus fogyasztói oldaláról olyan aktív részvételt feltételez, melyben az egyének önkéntesen veszik igénybe a legújabb irányzatokat követő egészség szolgáltatásokat. Az egészségturizmusban való proaktív részvétel alapján, ez az ágazat az egészségtudatosság komponenseként jelenik meg [31], melyben az átmeneti életmódváltáshoz elengedhetetlen, koncentráltan összeállított szolgáltatáscsomagokkal, gyakran luxuskörülmények között, szakavatott személyzet segítségével regenerálják a vendégek szervezetét [19].

A wellness turizmus olyan állandó lakhelyen kívüli ideiglenes tartózkodást jelent, mely során a cél az optimális egészségi állapot elérése, a testi, lelki és szellemi egyensúly megteremtése és - ugyan nem mindenki érkezik határozott egészségmegőrző, egészségfejlesztő célokkal - hatása motivációtól függetlenül is megjelenik. Az alábbiakban a kutatási területek kapcsolódási pontját és az elért eredményeket a turizmusban eddig rendelkezésre álló hazai és külföldi vizsgálatok alapján részletezem.

Az egészségturizmus hatásvizsgálatai hazai viszonylatban fóként az 1990-as évek végétől élénkültek fel. A vizsgálatok irányai gazdasági és társadalmi [29, 30], földrajztudományi [7, 8, 9], egészségügyi [6, 10], szociológiai [16] kérdéseket ölelnek fel. A turizmus életminőség javítását szolgáló kutatásai körében Pál és Uzzoli (1996, 2008), Utasi (2007), valamint Michalkó (2010), valamint Michalkó és mtsai (2013) neve említendő.

Egyéni érdekeken túl, társadalmi és gazdasági cél az egészség védelme és annak hosszan tartó megőrzése. A betegségmegelőzés, egészség megőrzése, fejlesztése gazdasági és innovációs szempontból is hangsúlyos terület. Alapul véve a tényt, miszerint az egészséggel kapcsolatos rendezvények hozzájárulnak ezen ismeretek terjesztéséhez [14], az egészségturizmusban rejlő potenciálok kihasználása is hangsúlyosabban jelenhet meg a témában érintett szakemberek számára. Az egészség jegyében eltöltött turisztikai utazás a pihenés, a rekreáció, az energiatartalékok feltöltéséhez járul hozzá elsődlegesen, másodlagosan viszont szerepe lehet az intézményes keretek között elsajátított ismeretek aktualizálásában, kibővítésében, képességek csiszolásában és kedvező attitűdök kialakításában [40], értelmezésem szerint szorosan kapcsolódva az egészségnevelés legfóbb céljához, ami az ismeretek elsajátítása révén attitüd és magatartásváltozást von maga után.

\subsection{Informális tanulás a szabadidős tevékenységekben}

Az informális tanulási forma szabadidős tevékenységekben való megjelenésére - ugyan eltérő súlyozással - mutat példát a szakirodalom. 
Horváth H. Attila [12] közösségi színterek (település, család, grund, vendéglő, sportegyesület) kapcsán tett kutatása alapján jutott arra a következtetésre, hogy a fentebbi terülteken szerzett tudások a vizsgált személyek későbbi életére is hatást gyakorolnak.

Médiaandragógia és informális tanulás kapcsolatát vizsgálta Stéber Andrea [35] , aki a média szórakoztató és egyben ismeretterjesztő funkciójára világított rá. Külön hangsúlyt fektetett a mindennapokhoz köthető, televíziós sorozatok felnőttekre gyakorolt hatására. A képernyőn látottak lényegét az érzelmekre, gondolatokra ható reakciók (megbeszélés másokkal) révén állapította meg. Kutatási eredményei a média személyiségre, ismeretekre és társas élményekre gyakorolt hatását támasztották alá.

Stéber és Kereszty az informális tanulás szakirodalmi vonatkozásait időkeret, mód és színtér szerint csoportosítják. Megállapításuk szerint az informális tanulás gyakran a nem formális tanulás kísérőjeként, ugyan legtöbbször a munkához és kevésbé a szabadidős tevékenységekhez kötik, ám utóbbit „szinte kimeríthetetlen lehetőségeket rejtő tanulási formaként” jellemzik [36].

Fentebb említett kutatások révén a szabadidőhöz kapcsolt informális tanulás jelenléte nyilvánvaló. Így az egészségturizmus területének feltárása alátámasztott.

\subsubsection{Informális tanulás a turizmusban}

A turizmus általános értelemben vett formájában az informális tanulás szociális kompetenciákra gyakorolt hatását vizsgálta Simándi Szilvia [34]. Turizmus fajtái alapján pedig „szelíd turizmus", azon belül környezetbarát és ÖKO-turizmus [1, 2, 3, 25, 37, 13, 22, 23], valamint a kulturális turizmus $[5,26]$ területén jelentek meg tanulmányok.

A turizmus területén végzett tanuláskutatások szakirodalmi megjelenése az utóbbi 20 évre tehető. Az intézményes kereteken túl létező tanulási formák és azok hatásának vizsgálatai azonban többféleképpen jelennek meg. A turizmus kontextusában rendelkezésre álló kutatások egymással sokszor átfedésben turizmusforma, tanulás fajtája, módszer és kutató valamint kutatócsoportok alapján csoportosíthatóak.

Előbbiekben az informális tanulás színtereit csak érintőlegesen, a csoportosítás részeként említettem, az alábbi fejezetben azonban azt a két (jelen kutatáshoz szorosan kapcsolódó) külföldi szakirodalmat mutatom be, melyek a témában már eddig elért, számomra irányadó eredményeket tártak fel.

\subsection{Turizmus során szerzett informális tanulás rövid távú hatása a magatar- tásban}

Jelen kutatás az ökoturisztikai utazások során szerzett informális ismeretek magatartásra gyakorolt hatásának rövid távú eredményei szerint két kutatással hozható összefüggésbe.

Hughes, Packer és Ballantyne [13] az ökoturisztikai interpretációs tevékenységek és az azt követő, további ismeretek elsajátítását segítő online anyagok természetvédelmi ismeretekre, attitűdre és viselkedésre gyakorolt hatását vizsgálta. Eredményeik alapján a látogatás után a vadaspark élőlényeire vonatkozó természetvédelmi ismeretekben nem, azonban a hoszszú távú ismeretekre ható üzenetek, fórumok az érzékelt tudás a globális természetvédelmi stratégiára, attitűdre és viselkedésre vonatkozóan szignifikáns különbséget mutatott a kísérleti és kontroll csoport között. A látogatást követő információk ebben az értelmezésben a vadaspark élővilágára vonatkozóan többlet információt nem adtak, ám a környezetvédelem tágabb értelmezését, annak mindennapi tevékenységeikbe való integrálásását (szelektív hulladékgyüjtés, energiatakarékosság, tömegközlekedési eszközök preferálása, önkéntes munka, komposztálás) nagyban segítette.

Ugyancsak a vadvilág védelme iránti tudatosság növelés motiválta Ballantyne, Packer és Falk [3] vizsgálatát, melyben a hosszú távú tanulás és környezeti magatartásváltozás tényezőit keresték. A tényezők azonosítása három lépésben, előzetes környezeti orientációt, turisztikai motivációt, rövid és hosszú távú tudást, valamint viselkedésváltozást feltáró kérdőívvel történt. A hosszú távú tudás befolyásoló tényezői között a vadaspark reklámeszközeit, a látogatás előtt már fennálló környezetvédelem iránti elkötelezett magatartást, illetve a részvétel során tapasz- 
talt reflektív élményt említették. Utóbbi esetén azonban kiemelték, hogy a reflektív élmény inkább a rövidtávú tudás meghatározó tényezője, és mint ilyen, közvetve gyakorol szignifikáns, de gyenge hatást a fennmaradó változásokra.

Fentebb bemutatott kutatások közös jellemzője, hogy a tanulást adott és metodológiailag gondosan megtervezett környezetbe ágyazott formájában vizsgálja. Látható, hogy az eltérő motivációval érkezés és a megkülönböztetett látogatómenedzsment eszközök alkalmazása ellenére, a tanulás élménye nem tér el szignifikánsan a kontrollcsoportos kutatásokban sem. Feltételezhető, hogy a tanulási folyamat és a viselkedésváltozásra irányuló szándékbefolyásoló tényezője a látogatás során kialakuló érzelmi befolyásoltság, mely további megerősítés nélkül rövid időn belül nem okoz viselkedésbeli változást. A lentebb bemutatott eredmények azonban abban mutatnak eltérést, hogy a magatartás változása pedagógiai megalapozottság nélkül is megjelennek.

\section{Módszertan}

A kutatás színterét jelen vizsgálatban Molnár [20] egészségturizmus felosztásának wellness területe adta.

A kutatás a következő kérdésre kereste a választ:

Az utazás során kialakult viselkedési szándék ideiglenesen befolyásolja-e a megkérdezettek utazást követő egészségre jótékonyan ható magatartását?

A kérés megválaszolására 393 fó online, további 335 fő személyes megkérdezése révén került sor. Az online felmérés az Unipoll Kérdőívszerkesztő Rendszerén elkészített kérdőív linkjének közösségi portálokon való megosztásával történt, de az alacsony válaszadási hajlandóság miatt, a minta bővítése céljából a személyes megkérdezést is szükségesnek tartottam, amit a budapesti (2017. március 2.) és a szolnoki (2017. április 8.) Utazás Kiállításon hajtottam végre. A kutatási mintát végül 704 személy alkotta.

A vizsgálat során az SPSS 25.0 program próbaverzióját alkalmaztam, az eredmények diagramjait Microsoft Excel programmal szerkesztettem. Az eredmények könnyebb átláthatósága érdekében az utazás során kialakult viselkedési szándék, utazást követő magatartásra gyakorolt hatásának eredményei közül csak azokat tüntettem fel és szemléltetem ábrákkal, melyek szignifikáns, illetve statisztikailag magyarázható eredményeket mutattak.

A kérdőív előzetes tesztelése (faktoranalízis, cronbach-alfa számítás) során kapott eredmények [32] alátámasztották, hogy a mérőeszköz alkalmas a célok megvalósítására, így a kérdés megválaszolására nem paraméteres próbák közül a Kruskal - Wallis tesztet [11], a leíró statisztikai módszeren belül, az eredmények megerősítésére medián és módusz [17] számításokat alkalmaztam.

A kutatás korlátai között említendő, hogy anyagi okok miatt az online lekérdezés ideje 2016. november 24 - 2017. március 04-ig terjedő időszakra esett, a megkérdezettek az egészségturizmuson belül leginkább a wellness turistákra korlátozódtak, valamint életkori megoszlásuk tekintetében a vizsgálati eredmények a 21 év fölötti egyénekre érvényesek.

\section{Eredmények}

Az utazás során kialakult viselkedési szándék és az aktuális magatartásra ideiglenesen ható tényezők feltárása érdekében egyenként vetettem össze az aktuális magatartás független változóihoz tartozó egészséggel kapcsolatos viselkedési szándék - Likert skálán mért - függő változóit (1. táblázat).

Az utazás során kialakult viselkedési szándék és az aktuális magatartás időleges hatásának kapcsolatában egy igazolható szignifikáns kapcsolatot találtam (1. táblázat).

A 'kitalálok egy technikát, hogy ne felejtsek elmenni szűrővizsgálatokra' kijelentés ugyan csak időlegesen, de ebben a kérdéskörben is szignifikáns (KW teszt - o,011) értékkel jelent meg az eredmények között (1. táblázat). Az ismeretek hatására kialakult viselkedési szándék területén már az ökoturizmus jeleskedik vizsgálati eredményekkel [3, 13]. Esetükben a kutatási eredmények azt támasztják alá, hogy az utazás során kialakult szándék fóként érzelmi meghatározottság alatt áll, ami gyenge tényező annak hosszú távú, viselkedésben való megnyilvánulásában. 
1. táblázat: Utazás során kialakult egészséggel kapcsolatos viselkedési szándék ideiglenes hatása az aktuális magatartásra

\begin{tabular}{|c|c|c|c|}
\hline Viselkedési szándék & $\begin{array}{l}\text { Aktuális magatartás } \\
\text { (utazásom után egy } \\
\text { ideig igaz volt rám) }\end{array}$ & $\begin{array}{c}\text { Medián } \\
\text { teszt }\end{array}$ & $\begin{array}{c}\text { Szignifikancia } \\
\text { szint }\end{array}$ \\
\hline $\begin{array}{l}\text { A jövő́ben jobban odafigyelek a } \\
\text { munka és a pihenés arányára, az } \\
\text { egészséges életvitel kialakítására }\end{array}$ & $\begin{array}{l}\text { Odafigyelek a munka és a } \\
\text { pihenés arányára, az egész- } \\
\text { séges életvitel kialakítá- } \\
\text { sára. }\end{array}$ & 0,565 & 0,353 \\
\hline $\begin{array}{l}\text { A munkahelyi körülményeimet úgy } \\
\text { szervezem, hogy tudatosabban tud- } \\
\text { jak táplálkozni }\end{array}$ & Tudatosabban táplálkozok. & 0,151 & 0,139 \\
\hline $\begin{array}{l}\text { A jövőben figyelni fogok a megfe- } \\
\text { lelő folyadékpótlásra }\end{array}$ & $\begin{array}{l}\text { Figyelek a megfelelő foly- } \\
\text { adékpótlásra. }\end{array}$ & 0,000 & 0,031 \\
\hline \multirow[t]{2}{*}{$\begin{array}{l}\text { Kitalálok egy technikát, hogy ne } \\
\text { felejtsek elmenni szürővizsgála- } \\
\text { tokra }\end{array}$} & $\begin{array}{l}\text { Rendszeresen eljárok } \\
\text { szürővizsgálatokra. }\end{array}$ & 0,003 & 0,011 \\
\hline & & nem & igen \\
\hline \multirow{2}{*}{$\begin{array}{l}\text { Medián } \\
\text { Módusz }\end{array}$} & & 4 & 5 \\
\hline & & 4 & 5 \\
\hline $\begin{array}{l}\text { A jövőben igyekszem aktívan töl- } \\
\text { teni a szabadidőmet }\end{array}$ & $\begin{array}{l}\text { Aktívabban töltöm a szaba- } \\
\text { didőmet. }\end{array}$ & 0,004 & 0,071 \\
\hline $\begin{array}{l}\text { Ahová lehet gyalog vagy kerékpár- } \\
\text { ral megyek }\end{array}$ & $\begin{array}{l}\text { Ahová lehet gyalog vagy } \\
\text { kerékpárral megyek. }\end{array}$ & 0,078 & 0,067 \\
\hline $\begin{array}{l}\text { Megpróbálom a sport, fizikai aktivi- } \\
\text { tás kevésbé költséges formáját az } \\
\text { életem részévé tenni }\end{array}$ & $\begin{array}{l}\text { A sport, fizikai aktivitás az } \\
\text { életem része. }\end{array}$ & 0,822 & 0,359 \\
\hline $\begin{array}{l}\text { A jövőben célirányosabb informáci- } \\
\text { ókat, ismereteket szerzek majd a } \\
\text { betegségmegelőzés, egészségmeg- } \\
\text { őrzés egyes formáiról }\end{array}$ & $\begin{array}{l}\text { Tudatosabban keresem a } \\
\text { betegség-megelőzés, egész- } \\
\text { ségmegőrzés, gyógyulás } \\
\text { egyes formáihoz kapcso- } \\
\text { lódó ismereteket. }\end{array}$ & 0,507 & 0,929 \\
\hline
\end{tabular}

Az eredmények alakulásában valószínüsíthető, hogy hasonlóan a külföldi adatokhoz, a válaszadók a rendszeres szűrővizsgálatok látogatása esetén, a magatartásuk fenntartásához szükséges motiváló hatás nélkül visszaállnak utazásuk előtti szokásaikhoz. Időleges hatás a megkérdezettek egyetértésével 39,2\%-ban, teljes mértékű egyetértésével 13,5\%-ban alakult ki (1. ábra).

A szürővizsgálatok jelentősége a kutatás egészében többször is megjelent [33]. Ennek hatása véleményem szerint ugyancsak befolyásoló tényezőként jelent meg annak időleges fennmaradásában. A külföldi szakirodalom a viselkedés időleges változására az ökoturizmus területén rendelkezik adatokkal $[3,13]$. Kutatásaik azt támasztják alá, hogy a környezetvédelemre irányuló viselkedési szándék változásai érzelmi meghatározottságúak, melyek hatása csak átmeneti viselkedésváltozást eredményez. Az eddig elért eredmények ebben a vonatkozásban is megerősítést nyertek és bár a vizsgálat a viselkedési szándék változásának kiváltó tényezőire nem tér ki, feltételezhető, hogy az egészségturisztikai utazások során átélt tapasztalatok hatásai ennél a területnél is csak olyan mértéküek, melyek a válaszadók viselkedésében átmeneti motiváló tényezőként vannak jelen. 


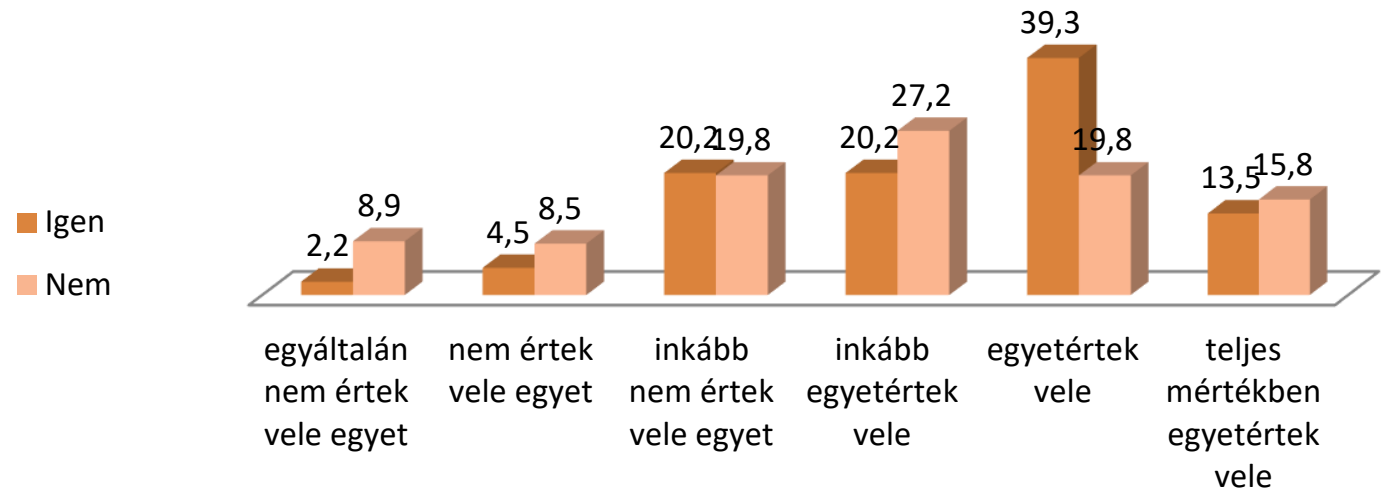

1. ábra: Utazás során kialakult egészséggel kapcsolatos viselkedési szándék - Kitalálok egy technikát, hogy ne felejtsek elmenni szürövizsgálatokra. - ideiglenes hatásának összefüg-

gése (\%)

\section{4. Összefoglalás}

Az utazás során kialakult viselkedési szándék aktuális magatartásra gyakorolt hatása a szürővizsgálatok terén, átmeneti fennmaradással ugyan, de igazolást nyert. A kérdéskör tesztelésénél már említett vizsgálatok $[3,13]$ a környezetvédelemre irányuló viselkedési szándék időleges, környezetvédő magatartásban megnyilvánuló formáját már kimutatták. Eredményeik magyarázatát abban látták, hogy az adott turisztikai helyszínen, élmények hatására kiváltott érzelmek játszanak szerepet a viselkedési szándék kialakulásában, mely gyenge, vagyis rövid távon befolyásolja annak konkrét környezetvédő tevékenységekben is megjelenő formáját. Külön említést érdemel, hogy a kutatási eredmények interpretációs eszközök segítsége mellett születtek, míg esetemben ezek az eredmények annak hiányában is megjelentek.

Az egészségmagatartás pozitív irányú megnyilvánulásainak feltételei az előbbiekben értelmezett eredmények kapcsán már ismertté váltak (attitűd erőssége, önhatékonyság, képességek, készségek, korlátozó tényezők). Bebizonyosodott, hogy a szerzett ismeretek befolyásolták a szándék kialakulását [33], mely szándék, az egészség javítására irányuló tevékenységet csak rövid ideig tartotta fent. Az egészségmagatartás kedvező irányú befolyásolása több tényező együttes hatásának függvénye, így az egészségnevelés több irányból kész különféle intervenciókkal hatást gyakorolni azokra, akikben megfogalmazódik a szándék, de képtelenek azt végrehajtani, valamint akikben gyenge vagy ki sem alakult a szándék [21]. A kutatásom során kapott eredmények azt támasztják alá, hogy az utazás, természetéből fakadóan, tudatosan alkalmazott interpretációs eszközök alkalmazása nélkül is képes az egészségvédő magatartás szándékának kialakítására, azonban annak megnyilvánulására, vélhetően a teljesítéshez szükséges feltétel/feltételek megszűnésével, rövid ideig gyakorol hatást, így a késóbbiekben a tevékenység rövidtávon történő fennmaradásának okaira is célszerü lenne rávilágítani.

\section{Felhasznált irodalom}

[1] Ballantyne, R. - Packer, R. (2009): Introducing a fifth pedagogy: experience-based strategies for facilitating learning in natural environments. Environmental Education Research, 15. 2. 243-262.

[2] Ballantyne, R. - Packer, R. (2005): Promoting environmentally sustainable attitudes and behaviour through free-choice learning experiences: What is the state of the game? Environmental Education Research, 11. 3. 281-295.

[3] Ballantyne, R., Packer, J., Falk, J. (2011): Visitors' learning for environmental sustainability: Testing shortand long-term impacts of wildlife tourism experiences using structural equation modelling. Tourism management, 32. 1243-1252

[4] Ballantyne, R., Packer, J., Sutherland, L.A. (2011): Visitors' memories of wildlife tourism: Implications for the design of powerful interpretative experiences. Tourism Management, 32. 770-779.

[5] Bamberger, Y. - Tal, T. (2006): Learning in a personal context: Levels of choice in a free choice learning environment in science and natural history museums. Science Learning in Everyday Life. 2. 75-95.

[6] Borbás Ilona, Kincses Gyula (2007): Egészségügyi ellátó rendszerek az Európai Unió Tagállamaiban. Egészségügyi Stratégiai Kutatóintézet, Egészségügyi Rendszertudományi Iroda, Budapest, 8-16. 
[7] Dávid Lóránt, Bujdosó Zoltán, Tóth Géza (2008): Tourism planning in the Hajdú-Bihar - Bihor Euroregion, In: Süli-Zakar I. (szerk.): Neighbours and partners: on the two sides of the border, Konferenciakötet, Debrecen, 323-332.

[8] Dávid Lóránt, Szűcs Csaba (2009): Building of networking, clusters and regions for tourism in the Carpathian Basin via information and communication technologies Netcom - Networks And Communications Studies 23. 1-2. 63-74.

[9] Dávid Lóránt, Tóth Géza, Bujdosó Zoltán, Remenyik Bulcsú (2011): The role of tourism in the development of border regions in Hungary, Romanian Journal of Economics, 32. 2. 109-124.

[10] Dézsy József (2001): Mi az egészségünk értéke? In: Egészségügyi Gazdasági Szemle 39. 4. 316-323.

[11] Fidy Judit, Makara Gábor (2005): Biostatisztika, Digitális Tankönyvtár, http://www.tankonyvtar.hu/hu/tartalom/tkt/biostatisztika-1/ch09s02.html [letöltve: 2017.07.06.]

[12] Horváth H Attila (2012): Az informális tanulás színterei a két világháború között, LÉTÜNK, 3• 99-119.

[13] Hughes, K., Packer, J., Ballantyne, R. (2011): Using post-visit action recources to support family conservation learning following a wildlife tourism experience, Environmental Education Learning, 17. 3. 307-328.

[14] Kalmár Katalin, Kiss Katalin (2009): Fogyasztói szokások vizsgálata a II. Wellness és Életmód kiállításon, Economica, A Szolnoki Főiskola Tudományos Közleményei Különszám, 56-62.

[15] Kimmel, J.R. (1999): Ecotourism as environmental learning. Journal of Enviromental Education, 30. 2. 4045 .

[16] Kopp Mária, Pikó Bettina (2004): A kultúra és életminőség kapcsolata. In: Bácsy, E. - Mikola, I.: Civilizáció és egészség. MTA Stratégiai Kutatások sorozat, Budapest, 139-158.

[17] Malhotra, N.K. (2008): Marketingkutatás, Akadémia Kiadó, Budapest, 503, 512.

[18] Michalkó Gábor (2010): Boldogító utazás: a turizmus és az életminőség kapcsolatának magyarországi vonatkozásai, MTA Földrajztudományi Kutatóintézet, Budapest, 119.

[19] Michalkó Gábor, Bakucz Márta, Rátz Tamara (2013): The relationship between tourism and residents' life quality: A case study of Harkány, Hungary, European Journal of Tourism Research, 6. 2. 154-169.

[20] Molnár Csilla (2011): Az egészségturiszikai fejlesztések hatásai, különös tekintettel Kelet-Magyarországra, Doktori (PhD) Értekezés, Széchenyi István Egyetem, Regionális és Gazdaságtudományi Doktori Iskola, Győr

[21] Nagy Lászlóné, Barabás Katalin (2011): Az egészségműveltség és egészségmagatartás diagnosztikus mérésének lehetőségei In: Csapó Benő - Zsolnay Anikó (szerk): Kognitív és affektív fejlódési folyamatok diagnosztikus értékelésének lehetõségei az iskola kezdõ szakaszában, Nemezeti Tankönyvkiadó, Budapest, 173224.

[22] Orams, M.B. (1997): The effectiveness of envrionmental education: Can we turn tourists int 'Greenies'? Progress in Tourism and Hospitality Research, 3. 295-306.

[23] Orams, M.B. (2002): Feeding wildlife as a tourism attraction: a review of issues and impacts. Tourism Management. 23. 281-293.

[24] Orosz Éva, Kollányi Zsófia (2016): Egészségi állapot, egészség-egyenlőtlenségek nemzetközi összehasonlításban, In: Kolosi Tamás, Tóth István György: Tárki Társadalmi Riport 2016. 334-357. http://www.tarki.hu/hu/publications/SR/2016/16orosz.pdf [letöltve: 2016.10.26.]

[25] Packer, J. (2006): Learning for fun: The unique contribution of educational leisure experiences. Curator, 49. 3. 329-344.

[26] Packer, J., Ballantyne, R. (2004): Is educational leisure a contradiction in term?: Exploring the synergy of education and entertainment, Annal of Leisure Research, 7. 1. 54-71.

[27] Packer, J., Ballantyne, R. (2010): The role of zoos and aquariums in education for sustainable future, New Directions for Adult and Continuing Education, 2010. 127.

[28] Pál Viktor, Uzzoli Annamária (2008): Az emberiség egészsége - a 21. század kihívásai, Földrajzi Közlemények, 132. 4. 471-488.

[29] Rátz Tamara (1999): A turizmus társadalmi-kulturális hatásai, Doktori (PhD) értekezés, Budapesti Corvinus Egyetem, Gazdálkodástani Doktori Iskola, 19-25.

[30] Rátz Tamara (2004): Zennis és Lomi Lomi avagy új trendek az egészségturizmusban. In: Aubert A, Csapó J (szerk.): Egészségturizmus, Főikolai jegyzet, Pécs, PTE TTK Földrajzi Intézet, 46-65.

[31] Rátz Tamara, Michalkó Gábor (2011): Dettineering és IVF kezelés - trendek a globális egészségturizmusban In: Michalkó Gábor - Rátz Tamara: Egészségturizmus és életminőség Magyarországon, Magyar Tudományos Akadémia, Földrajztudományi Kutatóintézet, Budapest, 13-26.

[32] Savella Orsolya, Horváth H Attila, Dudás Péter, Fritz Péter (2017a):"Informális tanulás az egészségturizmusban" mérésére alkalmas kérdőív tesztelése faktoranalízis és Cronbach-teszt alkalmazásával Magyar Sporttudományi Szemle 18. 69. 30-36.

[33] Savella Orsolya, Horváth H. Attila, Csizmásné Tóth Judit, Dudás Péter (2017b): Az egészségturisztikai utazások során szerzett ismeretek hatása az egészséggel kapcsolatos viselkedési szándék kialakulására, Gradus, 4. 2. 91-97.

[34] Simándi Szilvia (2012): Ifjúság - turizmus - tanulás. Az ifjú korosztály turisztikai magatartása, Belvedere Meridionale Kiadó, Szeged, 113-164.

[35] Stéber Andrea (2014): Az informális tanulás lehetőségei, Tudásmenedzsment, 15. 1. 13-28.

[36] Stéber Andrea, Kereszty Orsolya (2015): Az informális tanulás értelmezései a XXI. században, Új Pedagógiai Szemle, 9-10. 46-60.

[37] Tisdell, C., Wilson, C. (2005): Perceived impacts of ecotourism on environmental learning and conservation: Turtle watching as a case study. Environment, Development and Sustainability, 7. 291-302

[38] Utasi Ágnes (szerk) (2007): Az életminőség feltételei. MTA Politikai Tudományok Intézete, Műhelytanulmányok Digitális Archívum (1). Budapest. 
[39] Varsányi Péter, Vitrai József (2016): Egészségjelentés 2016, Nemzeti Egészségfejlesztési Intézet, Budapest, 7. http://www.egeszseg.hu/szakmai oldalak/assets/cikkek/17-05/egeszsegjelentes-2016.pdf [letöltve: 2017.10.26.]

[40] Zsolnai József (1996): A pedagógia új rendszere címszavakban. Nemzeti Tankönyvkiadó, Budapest, 153. 